\title{
NEW DISTRIBUTIONAL DATA ON BRYOPHYTES OF POLAND, 15
}

\author{
Piotr Górski, Katarzyna Kiaszewicz
}

\begin{abstract}
Series "New distributional data on bryophytes of Poland (and Slovakia)" is a scientific bulletin of Bryological Section of Polish Botanical Society
\end{abstract}

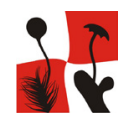

\section{Editors of the column: Piotr GóRsKI, AnNA RusińsKA}

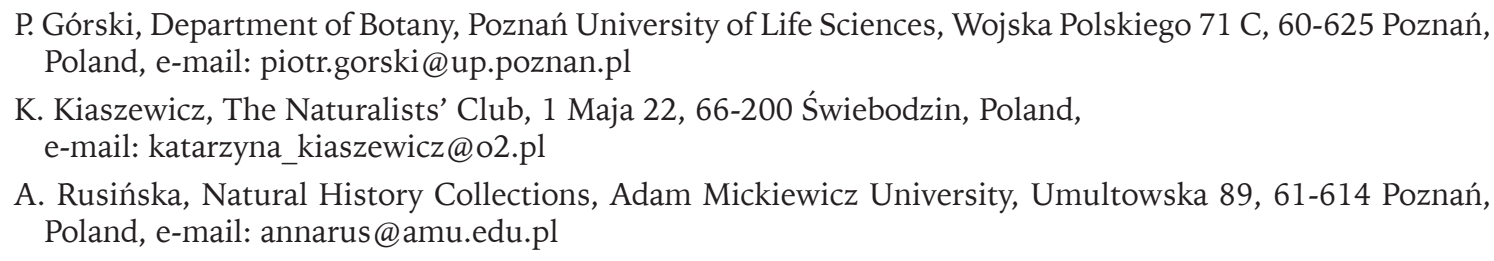

(Received: September 30, 2018. Accepted: October 22, 2018)

\begin{abstract}
AвstRact. This work presents a list of new localities for Calypogeia fissa, Cephaloziella elachista, Fuscocephaloziopsis catenulata, F. macrostachya, Isopaches bicrenatus, Odontoschisma denudatum, O. fluitans, and O. sphagni in Poland.
\end{abstract}

\section{Calypogeia fissa (L.) Raddi}

Author: P. GóRsKI

ATMOS Cb-22: NW Poland, West Pomerania, Drawa National Park (Drawieński Park Narodowy), near NE shore of Jezioro Ostrowiec lake, Kłocie Ostrowieckie rich fen, $53.10389^{\circ} \mathrm{N}, 15.98341^{\circ} \mathrm{E}, 53.10343^{\circ} \mathrm{N}$, $15.98335^{\circ} \mathrm{E}, 53.10394^{\circ} \mathrm{N}, 15.98316^{\circ} \mathrm{E}$, on peat, growing with Fuscocephaloziopsis connivens, leg., det. P. Górski, 21.07.2016 (POZNB).

The localities of Calypogeia fissa are concentrated in the western part of Poland (SZwEYKowsKi 2006). It is a relatively rare species (BUCZKOWSKA 2004) but not threatened in the country (KLAMA \& GóRSKI 2018). The liverwort seems to be more common than it would appear from the published data (SzWEYKOwsKI 1958, BUCZKOWSKA 2004, RosADZIŃSKI \& RusiŃSKA 2010, GóRski 2013). The first record of C. fissa in Drawa National Park was made by JASNOwsKA et al. (1986) but without detailed localization. New data published in this column confirm the occurrence of this liverwort in that area 30 years later.
2. Cephaloziella elachista (J.B. Jack ex Gottsche et Rabenh.) Schiffn.

Author: P. GóRSKI

ATMOS Cb-22: NW Poland, West Pomerania, Drawa National Park, Torfowisko Okragge bog, ca 600 $\mathrm{m}$ east from NE shore of Jezioro Ostrowiec lake, $53.10017^{\circ} \mathrm{N}, 15.99104^{\circ} \mathrm{E}$, growing with Mylia anomala, Fuscocephaloziopsis connivens, leg., det. P. Górski, 18.07.2016 (POZNB).

Cephaloziella elachista is known to exist in central and northern Poland (SzWEYKOwsKi 2006). It seems to be a rare, but not threatened (KLAMA \& GóRSKI 2018), poor fen species. However, in West Pomerania, it probably occurs more frequently than the published data indicate and is overlooked in the field. The presented new locality was observed in Drawa National Park. Until now, Cephaloziella elachista has not been found there. Previously, bryological research in this protected area was conducted by JASNOWSKA et al. (1986) and Koopman (2013). 
3. Fuscocephaloziopsis catenulata (Huebener) Váňa \& L. Söderstr. (=Cephalozia catenulata (Huebener) Lindb.)

Author: P. GóRSKI

ATMOS Af-86: NE Poland, Litewskie Lakeland (Pojezierze Litewskie), Puszcza Romincka Forest (Puszcza Romincka), 'Struga Żytkiejmska' nature reserve, $54.35055^{\circ} \mathrm{N}, 22.62586^{\circ} \mathrm{E}, 54.35100^{\circ} \mathrm{N}, 22.62694^{\circ} \mathrm{E}$, $54.35114^{\circ} \mathrm{N}, 22.62632^{\circ} \mathrm{E}$, decaying spruce log, Sphagno girgensohnii-Piceetum, leg., det. P. Górski, 17.09.2016 (POZNB).

Fuscocephaloziopsis catenulata is an epixylic species found in near-natural forests with the characteristics of a virgin forest (CIEśLIŃSKI et al. 1996). Based on studies in the Puszcza Białowieska primeval forest, this plant was classified as a so-called primeval forest relict (KlAmA in CieśLIŃSKI et al. 1996, KLAMA 2002b). To date, localities of F. catenulata in Poland have been reported in almost all mountain massifs and in the northern (primarily north-eastern) part of the country (SZWEYKowsKi 2006, GóRSKI \& RoMAŃSKi 2016). On a whole-country scale, $F$. catenulata is a species that is threatened with extinction (category V; KLAMA \& GóRSKI 2018). The new presented locality is in Puszcza Romincka Forest, where this species was reported recently (FoJcIK et al. 2017). New localities of F. catenulata, reported after 2000, are also known in north-eastern Poland (KLAma 2002a, b, GórsKi et al. 2014, GóRSKI \& ROMAŃSKI 2016).

4. Fuscocephaloziopsis macrostachya (Kaal.) Váňa et L. Söderstr. (=Cephalozia macrostachya Kaal.)

Authors: K. KIASZEWICZ, P. GóRSKI

ATMOS Bb-03: NW Poland, West Pomerania (Pomorze Zachodnie), Białogardzka Plain (Równina Białogardzka), $1.3 \mathrm{~km}$ north of Warnino village, 'Warnie Bagno' nature reserve, a big Baltic type raised bog, $54.14081^{\circ} \mathrm{N}, 15.94594^{\circ} \mathrm{E}$, on peat post excavation pits, in Sphagno tenelli-Rhynosporetum albae, leg., det. K. Kiaszewicz, 6.07.2018, conf. P. Górski (POZNB).

The distribution centre of Fuscocephaloziopsis macrostachya in Poland is situated in the northern part of the country (SzWEYKowski 2006). According to Szweykowski (l.c.), this species is actually more common than it would appear from the published data. This opinion confirms new localities documented in recent years in West Pomerania (Koszalin Coastland, GóRSKI 2013, GórsKi et al. 2015a; Sławieńska Plain, GóRSKI et al. 2016b; Wałcz Plain, GóRsKI et al. 2015b) and Puszcza Romincka Forest (north-eastern Poland, GóRSKI et al. 2016a). Fuscocephaloziopsis macrostachya is considered to be near threatened in Poland (category NT; KLAMA \& GóRSKI 2018).
5. Isopaches bicrenatus (Schmidel ex Hoffm.) H. Buch (=Lophozia bicrenata (Schmidel ex Hoffm.) Dumort.)

Author: P. GóRsKI

ATMOS Cb-22: NW Poland, West Pomerania, Drawa National Park, south from Jezioro Piaseczno Duże lake, $53.11951^{\circ} \mathrm{N}, 16.00346^{\circ} \mathrm{E}$, on mineral sandy soil near forest road in a young pine plantation, growing with Cephaloziella divaricata, leg., det. P. Górski, 20.07.2016 (POZNB).

Isopaches bicrenatus is a widespread lowland species that is not in danger of extinction in Poland (SZWEYKOWSKI \& KoźLICKA 1980, KLAMA \& GóRSKI 2018). The presented new locality was noted in Drawa National Park. Until now, I. bicrenatus has not been found there (see JASNOWSKA et al. 1986, KoopMAN 2013).

\section{Odontoschisma denudatum (Mart.) Dumort.}

Author: P. GóRskI

ATMOS Cb-13: NW Poland, West Pomerania, Drawa National Park, Głodne Jeziorka lakes, $53.19333^{\circ} \mathrm{N}$, $16.07436^{\circ} \mathrm{E}$, decaying pine log, growing with Nowellia curvifolia, Lepidozia reptans and Lophocolea heterophylla, leg., det. P. Górski, 20.07.2016 (POZNB).

Odontoschisma denudatum is the third (after Cephaloziella elachista and Isopaches bicrenatus) of the species that are new to the Drawa National Park presented in this column. The liverwort is relatively common only in the north-eastern part of Poland (SZWEYKOWSKi 2006). There are also known localities in the north-western and south-western parts of the country (SZWEYKOWSKI 1958, 2006, GóRSKI 2010, 2013). On a whole-country scale, this liverwort is considered to be near threatened (category NT; KLAMA \& GóRSKI 2018).

7. Odontoschisma fluitans (Nees) L. Söderstr. et Váňa (=Cladopodiella fluitans (Nees) H. Buch)

Authors: K. KIASZEWICZ, P. GóRSKI

ATMOS Bb-03: NW Poland, West Pomerania, Białogardzka Plain, $1.3 \mathrm{~km}$ north of Warnino village, 'Warnie Bagno' nature reserve, a big Baltic type raised bog, $54.14081^{\circ} \mathrm{N}, 15.94594^{\circ} \mathrm{E}, 54.14208^{\circ} \mathrm{N}$, $15.94053^{\circ} \mathrm{E}$, on peat post excavation pits, in Sphagno tenelli-Rhynosporetum albae, leg., det. K. Kiaszewicz, 6.07.2018, conf. P. Górski (POZNB); ATMOS Bb-74: NW Poland, West Pomerania, Pojezierze Drawskie (Drawskie Lakeland), ca $3 \mathrm{~km}$ southwest of Czaplinek town, 'Brzozowe Bagno koło Czaplin$\mathrm{ka}$ ' nature reserve, $53.5359972^{\circ} \mathrm{N}, 16.2050194^{\circ} \mathrm{E}$, in Caricetum limosae, leg., det. K. Kiaszewicz, 27.07.2018, c. per., conf. P. Górski (POZNB). 
The distribution characteristics of Odontoschisma fluitans in Poland were presented by KLAMA (1998). On a whole-country scale, this liverwort is considered to be near threatened (category NT; KLAMA \& GóRSKI 2018). Recent records of this species have been made in West Pomerania (GóRsKI 2013, GóRSKI et al. 2015a, b), the Lubuskie lakeland (GóRSKI et al. 2015a), the Tatra Mountains (GóRSKI et al. 2015a) and Puszcza Romincka Forest (GórsKi et al. 2016a).

\section{Odontoschisma sphagni (Dicks.) Dumort.}

Authors: K. Kiaszewicz, P. GóRsKI

ATMOS Bb-03: NW Poland, West Pomerania, Białogardzka Plain, $1.3 \mathrm{~km}$ north of Warnino village, 'Warnie Bagno' nature reserve, a big Baltic type raised bog, $54.13956^{\circ} \mathrm{N}, 15.92886^{\circ} \mathrm{E}, 54.14198^{\circ} \mathrm{N}$, $15.93041^{\circ} \mathrm{E}, 54.14314^{\circ} \mathrm{N}, 15.92929^{\circ} \mathrm{E}$, on peat, on fragments of natural peat cupola, in Erico-Sphagnetum magellanici, leg., det. K. Kiaszewicz, 6.07.2018, conf. P. Górski (POZNB).

Most of the polish localities of Odontoschisma sphagni are situated in the north-western part of the country (West Pomerania). In this area, the liverwort seems to occur more frequently than it would appear from the published data. Single records of this plant have also been reported in north-eastern and southern Poland (Szweykowski 2006). On a whole-country scale, $O$. sphagni is a species that is threatened with extinction (category V; KLAMA \& GóRSKI 2018). Since 2000, the liverwort has been recorded by RosADZIŃSKI \& RusińsKa (2010), GóRSKI (2013) and GórSKI et al. (2016b).

\section{ACKNOWLEDGEMENTS}

The contribution by Piotr Górski was supported by the Ministry of Science and Higher Education, Warsaw, Poland (statuory funds No 508.641.01).

\section{REFERENCES}

Buczkowska K. (2004): The genus Calypogeia Raddi (Jungermanniales, Hepaticae) in Poland, biometrical analysis of morphological and anatomical variation. Nova Hedwigia 78, 1-2: 121-146.

CieślińsKi S., CzyżEwsKa K., FalińsKi J.B., Klama H., MutenKo W., ŻarnowieC J. (1996): Relicts of the primeval (virgin) forest. Relict phenomena. In: J.B. Faliński, W. Mułenko (eds). Cryptogamous plants in the forest communities of Białowieża National Park. Functional groups analysis and general synthesis (Project Crypto 3). Phytocoenosis 8 (N. S.), Archivum Geobotanicum 6: 197-216.

Fojcik B., Zubel R., WierzchowsKa S., RosadziŃSKi S., Staniaszek-Kik M., RusińsKa A., Szczepański M.,
Vončina G., Wolski G., Ciurzycki W., Górski P., Piwowarski B., Pawlikowski P. (2017): Materiały do brioflory rezerwatu przyrody Boczki (Puszcza Romincka). Steciana 21, 4: 147-158.

GóRSKI P. (2010): A contribution to the liverwort flora of the Drawsko Lake district (Western Pomerania, Poland). Roczniki Akademii Rolniczej w Poznaniu 389, Botanika-Steciana 14: 19-26.

GóRSKI P. (2013): Wątrobowce (Marchantiophyta) Leśnego Kompleksu Promocyjnego „Lasy Środkowopomorskie" (Pomorze Zachodnie). PGL Lasy Państwowe Nadleśnictwo Karnieszewice, Wydawnictwo Uniwersytetu Przyrodniczego w Poznaniu, Sianów-Poznań.

Górski P., Kapustyński T., Kozub Ł., Dembicz I., Rosadziński S., Staniaszek-Kik M., RusińsKa A., Sмосzүк M. (2015a): New distributional data on bryophytes of Poland and Slovakia, 4. Steciana 19(4): 221-230.

GóRski P., PaWlikowski P., Staniaszek-KiK M., Rosadziński S., Stebel A., Rusińska A., Zubel R., Wilhelm M., Fudali E., CykowsKa-Marzencka B., Przewoźnik L. (2014): New distributional data on bryophytes of Poland, 1. Steciana 18, 2: 77-87.

GóRski P., Romański M. (2016): Fuscocephaloziopsis catenulata (Huebener) Váňa et L. Söderstr. - a liverwort new to Wigry National Park (north-eastern Poland). Steciana 20, 1: 45-52.

Górski P., Rusińska A., Smoczyk M., Dembicz I., Wierzcholska S., Kozub Ł., Romański M., Fudali E., PodLASKA M., WIADERNY A. (2016a): New distributional data on bryophytes of Poland and Slovakia, 5 . Steciana 20(1): 33-44.

Górski P., Smoczyk M., Pawlikowski P., Vončina G., Stebel A., Paciorek T., Staniaszek-Kik M., Romański M., Wiaderny A., GąbKa M., Wierzcholska S. (2015b): New distributional data on bryophytes of Poland, 2. Steciana 19(2): 55-65.

Górski P., Vončina G., SmoczyK M., KLAma H., Šoltés R., Wilhelm M., RutKowska M. (2016b): New distributional data on bryophytes of Poland and Slovakia, 8. Steciana 20(4): 191-200.

Jasnowska J., Jasnowski M., Grinn U., Friedrich S. (1986): Flora projektowanego Drawieńskiego Parku Narodowego i jej osobliwości. In: L. Agapow, M. Jasnowski (eds). Przyroda projektowanego Drawieńskiego Parku Narodowego. Gorzowskie Towarzystwo Naukowe, Gorzów Wielkopolski: 25-67.

Klama H. (1998): Nowe stanowisko Cladopodiella fluitans (Hepaticae, Cephaloziaceae) na Wyżynie Śląsko-Krakowskiej. Fragmenta Floristica et Geobotanica Polonica 5: 308-310.

KLAMA H. (2002a): Distribution patterns of liverworts (Marchantiopsida) in natural forest communities 
(Białowieża Primeval Forest, NE Poland). University of Bielsko-Biała, Bielsko-Biała.

Klama H. (2002b): Relikty puszczańskie we florze wątrobowców zbiorowisk leśnych Puszczy Białowieskiej. Zeszyty Naukowe ATH - Inżynieria Włókiennicza i Ochrona Środowiska 7, 3: 244-260.

Klama H., GóRski P. (2018): Red List of Liverworts and Hornworts of Poland ( $4^{\text {th }}$ edition, 2018). Cryptogamie, Bryologie 39, 4: 415-441.

Koopman J. (2013): Mszaki. In: Drawieński Park Narodowy. Operat szaty roślinnej. Vol. 1. Typescript. Dyrekcja Drawieńskiego Parku Narodowego, Świebodzin, Warszawa: 31-72.

RosADZiŃSKi S., RusiŃSKA A. (2010): Rzadkie i zagrożone wątrobowce polskiej części Dolnych Łużyc. In: A. Szczepkowski, A. Obidziński (eds). Streszczenia referatów i plakatów LV Zjazdu PTB. Planta in vivo, in vitro et in silico. Warszawa, 6-12 września 2010, Warszawa: 18; Acta Societatis Botanicorum Poloniae 79, supl. 1: 24.

SzweYkowski J. (1958): Prodromus florae hepaticarum Poloniae. Prace Komisji Biologicznej Poznańskiego Towarzystwa Przyjaciół Nauk 19: 1-600.
SzWEYKowsKi J. (2006): An annotated checklist of Polish liverworts and hornworts. - Krytyczna lista wątrobowców i glewików Polski. Biodiversity of Poland. Vol. 4. W. Szafer Institute of Botany, Polish Academy of Sciences, Kraków.

SZWEYKowsKi J., KoźLICKA M. (1980): H. 97. Isopaches bicrenatus (Schmiedel) Buch. In: J. Szweykowski, T. Wojterski (eds). Atlas of geographical distribution of spore plants in Poland. Vol. 10. Serie IV. Liverworts (Hepaticae). Polska Akademia Nauk, Poznańskie Towarzystwo Przyjaciół Nauk, Poznań.

For citation (1): Górski P., KiAsZeWICZ K. (2018): New distributional data on bryophytes of Poland, 15. Steciana 22, 3: 97-100. doi: 10.12657/ steciana.022.011

For citation (2): KIASZEWICZ K., GóRSKI P. (2018): 8. Odontoschisma sphagni (Dicks.) Dumort. In: P. Górski, A. Rusińska (eds). New distributional data on bryophytes of Poland, 15. Steciana 22, 3: 99. doi:10.12657/steciana.022.011 